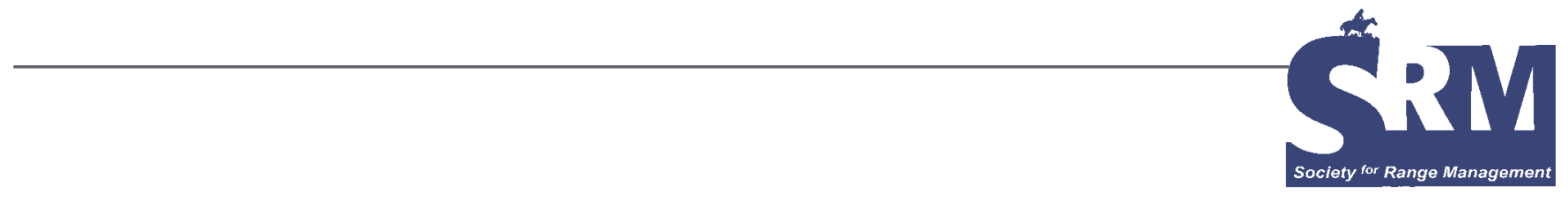

\title{
A Physiological Basis for Controlling Leafy Spurge on Nebraska Rangeland
}

\section{Applying herbicides at the appropriate physiological stage is an important consideration to effectively control leafy spurge.}

\section{By Rob Mitchell, Corey Moffet, and Ron Sosebee}

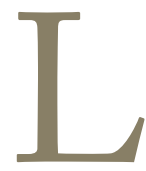

eafy spurge (Euphorbia esula L.) is a nonnative perennial forb that has invaded rangeland and pasture in the central and northern Great Plains of the United States and Canada. Leafy spurge has been reported in 35 states and all but one Canadian province $^{1}$ and is a noxious weed in Nebraska and about 20 other states. $^{2}$ Its invasive nature is promoted by reproduction from seeds and adventitious buds on the crown and roots. It quickly increases in pastures, alters rangeland species composition, and reduces forage production by as much as $75 \%$.,4

Leafy spurge has been difficult to reliably control with herbicides, with most herbicide treatments providing only short-term control. ${ }^{1}$ Current management strategies include herbicides as part of an integrated pest management program. ${ }^{5}$ However, few studies have used the physiological status of leafy spurge as an indicator to properly time herbicide applications.

The response to herbicides depends largely on the physiological status of the target plant. For herbicides to be effective, the plant must be susceptible to the herbicide, and it must be applied when the plant is most receptive to optimize absorption and translocation to the perennating tissues. Plants are most receptive to herbicides when soluble carbohydrates are being transferred to the perennating organs. The perennating organs in leafy spurge are the pink adventitious buds on the crown, roots, and rhizomes, which

This article has been peer-reviewed.

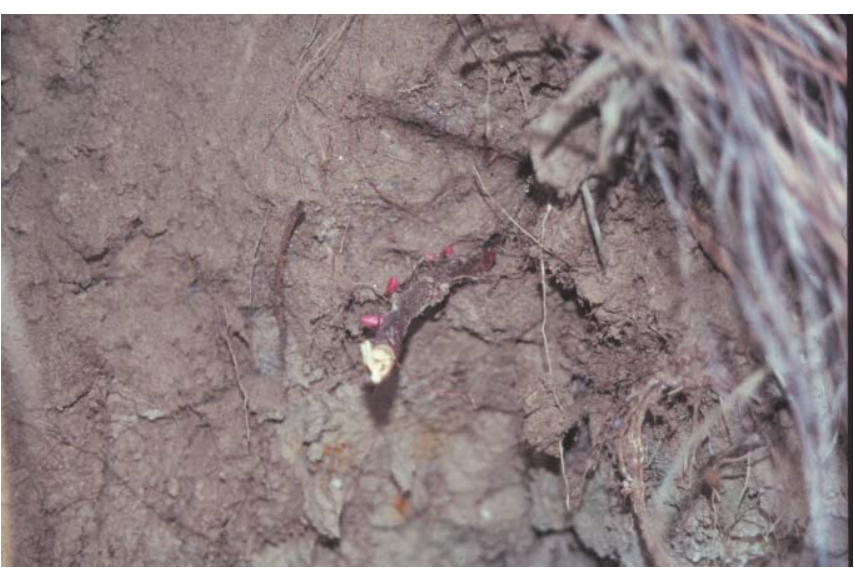

A leafy spurge rhizome exposed in the soil profile. The pink buds are active and will emerge as new shoots.

will emerge as new shoots in the spring. Most of these buds develop after flowering, in August and September.

Foliar-applied herbicides are translocated through the plant by moving soluble carbohydrates from energy sources (photosynthesizing leaves) to energy sinks. The energy sinks are the growing points of the plant or storage organs such as roots, rhizomes, or active buds.

Energy translocation and storage in plants can be determined by measuring the changes in total nonstructural carbohydrate (TNC) concentration in the plant material immediately adjacent to and below the plant crown. By measuring the TNC concentration monthly, its trend can be 
developed and closely associated with different stages of plant maturity. Our objective was to quantify the TNC trend for leafy spurge in Dawson County, Nebraska, and determine if timing herbicide applications based on TNC trend can improve our ability to predict leafy spurge response to herbicides.

We collected 10 leafy spurge plants at about 30-day intervals for 21 months in 1998 and 1999 from 4 geographic locations in Dawson County, Nebraska; measured the TNC concentration in the crown region; and developed a TNC trend for leafy spurge in Dawson County, Nebraska (Fig. 1).

The goal with foliar herbicide applications is to translocate the herbicide in the photosynthate stream and kill the plant and its buds. The most effective time to accomplish this goal is to apply foliar herbicides when TNC is increasing in the storage organs. Leafy spurge TNC increases in late February and early March (immediately before spring emergence) and again in mid-July through mid-October (after flowering; Fig. 1). Applying foliar herbicides in February and March would be ineffective because the plant is still dormant and has no exposed foliage. Many new leafy spurge buds form in late August and early September and signal the time to apply herbicides. Applying herbicides in July, August, or early September (periods of increasing TNC) would not be as effective because translocation does not occur at great enough levels to transport herbicides to the formed buds. Based on leafy spurge TNC, the best time to apply foliar herbicides to optimize mortality is from late September to the first killing frost (Fig. 1).

Picloram (Tordon $22 \mathrm{~K}^{\circledR}$; DowAgroSciences) has been used to effectively control leafy spurge. The broadcast application label recommendation is to apply 2-4 pints per acre at the true flower stage of growth or apply to autumn regrowth. In an effort to evaluate the influence of TNC on leafy spurge mortality, we broadcast applied picloram at 1 , 2 , and 4 pints per acre to 0.1 -acre plots in mid-June, midAugust, and mid-October to correspond with different

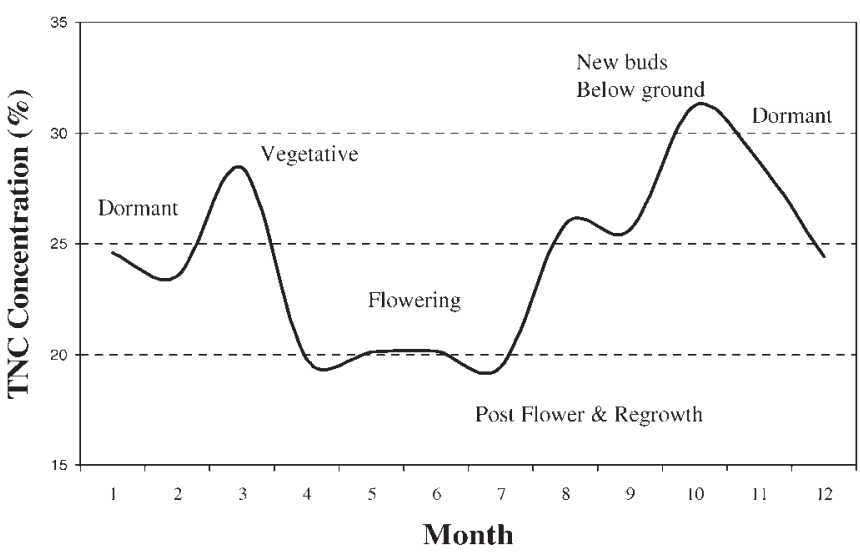

Figure 1. Leafy spurge total nonstructural carbohydrate (TNC) trend and associated stage of development in Dawson County, Nebraska. This trend represents the average TNC concentrations of leafy spurge collected from 4 sites in 1998 and 1999. stages of growth and TNC status (Fig. 1). In mid-June, the plants were in the flowering stage, and TNC was stable. In mid-August, the plants were in the postflower stage, and TNC was increasing. In mid-October, the plants were in the postflower stage, with new vegetative regrowth, new root development, increased TNC levels to near maximum, and had formed new lateral buds. The picloram treatments were applied at 2 locations in June, 1 location in August, and 1 location in October during 1999. The June treatments were applied during the flowering stage, the August treatments during the seed production stage, and the October treatments during the postflowering stage. Treatments were arranged as a completely random design and were replicated 3 times at each location. The treatment locations were typical Loess Hills mixed prairie and were grazed before and after treatment application. Treatments were adjacent to the sites where plants were collected for TNC evaluation. Leafy spurge live plant density was determined during the summer of 2001, nearly 24 months after the most recent treatment application.

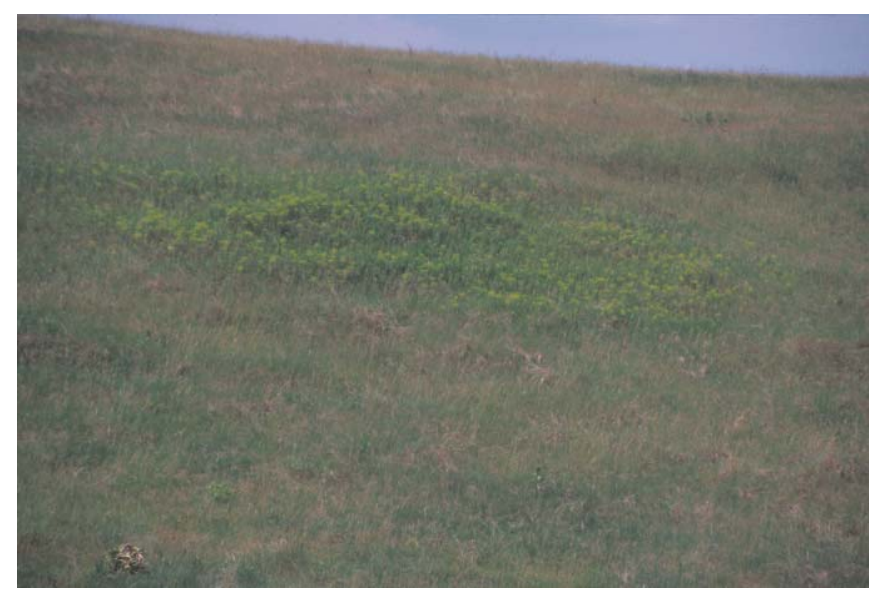

Leafy spurge growing on a nontreated site in the Loess Hills, Dawson County, Nebraska. Leafy spurge has displaced most of the native plant species and reduced forage production on this nontreated site.

None of the treatments applied in June during flowering were different from the controls (Table 1). However, the trend in June was for the number of live leafy spurge plants per square foot to decline (increased mortality) as picloram concentration increased (Table 1). In August, application of 1 or 4 pints of picloram per acre reduced leafy spurge density, but the application of 2 pints of picloram per acre was not different from the control. Although we cannot explain the lack of leafy spurge response to the 2-pint treatment in August, it appears that the variation in August was high as indicated by the large standard error (Table 1). In October, the 2-pint treatment reduced leafy spurge compared to the control, and the 4-pint treatment effectively eliminated leafy spurge in a uniform manner across treatment areas (Table 1). The 1-pint treatment was not different from the control, apparently because of the large variation across 
Table 1. Leafy spurge live plant density (number. $\mathrm{ft}^{-2}$ ) following applications of picloram (Tordon $22 \mathrm{~B}{ }^{\circledR}$ ) at 1, 2, and 4 pints per acre applied in June, August, or October in Dawson County, Nebraska in 1999. Live plant density for the control and all treatments was determined during the summer of 2001. Numbers in parentheses after the mean live plant density represent standard errors of the mean

\begin{tabular}{|c|c|c|c|c|}
\hline & \multicolumn{4}{|c|}{ Herbicide treatments } \\
\hline & Control & 1 pint-acre $^{-1}$ & 2 pints-acre ${ }^{-1}$ & 4 pints-acre ${ }^{-1}$ \\
\hline Application month & \multicolumn{4}{|c|}{ Live plants-ft ${ }^{-2}$ (SE) } \\
\hline June & $2.20(0.59)$ & $3.20(0.95)$ & $2.84(0.90)$ & $1.92(0.98)$ \\
\hline August & $2.66(0.69)$ & $1.57(0.37)$ & $2.97(1.11)$ & $1.07(0.49)$ \\
\hline October & $1.73(0.50)$ & $1.94(1.29)$ & $0.66(0.22)$ & $0.02(0.02)$ \\
\hline
\end{tabular}

treatment areas as indicated by the large standard error (Table 1).

With the exception of the 2-pint-per-acre treatment in August, the treatments responded as the TNC trend predicted. During flowering in June, the treatments did not acceptably reduce leafy spurge density. However, in October when the plants were in the regrowth and postflower stage with milky sap and new buds had been formed, leafy spurge mortality increased as picloram concentration increased. Leafy spurge was effectively eliminated with the 4-pintper-acre treatment in October.

Timing of herbicide application is critical to managing leafy spurge. For example, the picloram (Tordon $22 \mathrm{~K}^{\circledR}$, DowAgroSciences) label recommendation to apply to autumn regrowth is supported by our TNC data. For large, dense infestations application of picloram at $2-4$ pints per acre in autumn 2 weeks before the first killing frost is an effective treatment. Although not evaluated by us, a possible approach for follow-up treatment or treating small infestations would be to spot spray with 2,4-D in early June, then spot spray with picloram between September 15 and the first killing frost. Contract sprayers have reported that the spring 2,4-D treatment keeps the plants from producing viable seed, and the autumn picloram treatment kills the plants. It is important to remember that picloram application will kill many other forbs and woody plants, so use caution if desirable nontarget plants are present.

Based on leafy spurge TNC data collected from rangeland in central Nebraska, applying herbicides in autumn before the first killing frost will result in the best leafy spurge control. The label recommendations to apply Tordon $22 \mathrm{~K}^{\circledR}$ in the autumn to leafy spurge regrowth is supported by the physiological status of the plant populations.

Although herbicides are an important component in leafy spurge management, an integrated approach is required for successful leafy spurge control. In some cases, herbicide application followed by the release of biocontrol agents may prevent leafy spurge reinvasion. If infestations are well established and dense, it is likely that the grassland community has deteriorated to the point that even with leafy spurge control, desirable species are lacking and recovery will be unacceptably slow without additional management inputs. ${ }^{6}$ This scenario would require an integrated management plan including leafy spurge control with herbicides, followed by establishing stands of productive perennial grasses. With good posttreatment management, productive and competitive grasslands can be established and maintained to resist reinvasion by leafy spurge.

\section{Acknowledgments}

The authors wish to thank Steve Bauer, Bob and Pat Mitchell, Keith and Nancy Rudeen, and Larry and Jan Streit for allowing us the use of their pastures.

\section{References}

1. Anderson, G. L., E. S. Delfosse, N. R. Spencer, C. W. Prosser, and R. D. Richard. 2003. Lessons in developing successful invasive weed control programs. Journal of Range Management 56:1-12.

2. USDA, NRCS. 2004. The PLANTS database. Version 3.5. Available at: http://plants.usda.gov. Accessed 15 November 2007.

3. Lym, R. G., And D. R. Kirby. 1987. Cattle foraging behavior in leafy spurge-infested rangeland. Weed Technology 1:314-318.

4. Jacobs, J. S., R. L. Sheley, and J. L. Borkowski. 2006. Integrated management of leafy spurge-infested rangeland. Rangeland Ecology and Management 59:475-482.

5. Hodur, N. H., F. L. Leistritz, and D. A. Bangsund. 2006. Biological control of leafy spurge: utilization and implementation. Rangeland Ecology and Management 59:445-452.

6. Masters, R. A., And B. Kappler. 2002. Leafy spurge; biology, identification, distribution, and control. University of Nebraska Cooperative Extension Circular EC02-174-S.

Authors are Research Agronomist, USDA-ARS, Lincoln, NE 68583-0737, rob.mitchell@ars.usda.gov (Mitchell); Rangeland Scientist, USDA-ARS, Dubois, ID 83428-5032 (Moffet); and Professor Emeritus, Texas Tech University, Lubbock, TX 79409 (Sosebee). This paper is a joint contribution of the USDA-ARS, the University of Nebraska, and Texas Tech University. Mention of trade names or commercial products in this publication is solely for the purpose of providing specific information and does not imply recommendation or endorsement by the US Department of Agriculture, the University of Nebraska, or Texas Tech University. Always read and follow label directions. 